\title{
E-Modul Pembelajaran Coding Berbasis Pengenalan Budaya Indonesia untuk Meningkatkan Computational Thinking
}

\author{
Muthmainnah Harahap ${ }^{\circledR}{ }^{\bowtie}$, Delfi Eliza ${ }^{1}$ \\ Pendidikan Anak Usia Dini, Universitas Negeri Padang, Indonesia (1) \\ DOI: $\underline{10.31004 / o b s e s i . v 6 i 4.2314}$
}

\begin{abstract}
Abstrak
Pengenalan budaya sejak dini merupakan hal yang perlu diajarkan dalam melestarikan sosial budaya. Pengenalan budaya dapat dilaksanakan melalui pembelajaran coding yang merupakan inovasi pembelajaran dalam mengajarkan computational thinking anak yang memuat keterampilan dekomposisi, pengenalan pola, abstraksi dan algoritma. Salah satu inovasi yang dapat dilakukan dalam pembelajaran tersebut agar proses pembelajaran lebih menarik dengan mengembangkan sebuah e-modul. Penelitian ini bertujuan untuk mengetahui validitas, praktikalitas dan efektivitas e-modul pembelajaran coding berbasis pengenalan budaya Indonesia. Jenis penelitian yaitu reseach and development dengan model desain yaitu ADDIE. Hasil penelitian menunjukkan analisis angket validasi modul yaitu modul pembelajaran yang dikembangkan mencapai tingkat $87 \%$ dengan kategori sangat valid. Modul pembelajaran yang dikembangkan pada hasil uji praktikalitas sebesar 89,7\% dengan kategori sangat praktis. Modul pembelajaran yang dikembangkan pada uji efektivitas melalui kegiatan pretes dan postest mengalami peningkatan sebesar $88 \%$ dengan kategori sangat efektif.
\end{abstract}

Kata Kunci: e-modul pembelajaran coding; pengenalan budaya Indonesia; computational thinking.

\begin{abstract}
Introduction to culture early on things that need to be taught in preserving socio-culture. Cultural recognition can be implemented through coding learning which is a learning innovation that teaches children computational thinking that contains decomposition, pattern recognition, abstraction and algorithms. One of the innovations carried out in the learning so that the learning process is more interesting by developing an e-module. This research aims to find out the validity, practicality and effectiveness of e-modules based on the introduction of Indonesian culture. This type of research is reseach and development with a design model that is ADDIE. The results showed that the analysis of the validation questionnaire of learning modules developed reached $87 \%$ with a very valid category. Learning modules developed on practicality test results of $89.7 \%$ with very practical categories. Learning modules developed on effectiveness tests through pretest and postest activities increased by $88 \%$ with highly effective categories.
\end{abstract}

Keywords: e-module of coding learning; introduction of Indonesian culture; computational thinking.

Copyright (c) 2022 Muthmainnah Harahap, Delfi Eliza.

$\square$ Corresponding author:

Email Address : muthmainnahhrp@gmail.com (Padang, Sumatera Barat, Indonesia)

Received 23 November 2021, Accepted 5 February 2022, Published 14 February 2022 


\section{PENDAHULUAN}

Penelitian dan perubahan kebijakan beberapa tahun belakangan ini telah membawa fokus baru untuk membuat coding (Barron et al., 2011; National Association for the Education of Young Children (NAEYC) \& Fred Rogers Center, 2012). Coding sangat perlu diajarkan di dalam jenjang pendidikan sebab hampir semua pekerjaan di abad 21 membutuhkan teknologi sebagai media pendukung dalam pelaksanaan pekerjaan yang lebih efektif artinya kompetensi yang harus dimiliki semua orang di abad ini semakin meningkat termasuk anak usia dini. Anak usia dini yaitu anak yang berada pada rentang usia 0 sampai 8 tahun (NAEYC, 2004). Menurut Mayar (2019) anak usia dini adalah sosok yang sangat membutuhkan stimulasi secara maksimal dalam proses pertumbuhan dan perkembangan karena pertumbuhan dan perkembangan pada anak usia dini terjadi secara pesat.

Pendidikan Anak Usia Dini di abad 21 sudah perlu mengetahui cara memperkenalkan literasi baru berupa coding yang diajarkan sejak usia dini (Campbell \& Walsh, 2017) sebab Pendidikan Anak Usia Dini sangat penting untuk kualitas pengalaman anak (Eliza, 2013). Hal ini dapat diartikan bahwa Pendidikan Anak Usia Dini masa kini memahami coding sebagai literasi baru yang berguna untuk mengaktifkan cara berpikir baru dan cara baru untuk berkomunikasi dan cara untuk mengekspresikan ide. Melalui coding anak-anak memiliki literasi computational agar dapat membentuk anak menjadi produser dan bukan hanya konsumen dari artefak digital (Bers, 2020 :5). Pentingnya pembelajaran coding mempengaruhi Indonesia untuk ikut meningkatkan mutu pembelajaran sehingga pada tahun 2020 Kemendikbud meluncurkan program pembinaan penguatan kompetensi dan pengelolaan implementasi literasi dasar dalam menyiapkan generasi abad 21 melalui berbagai pendekatan dan diversifikasi kurikulum PAUD yang dapat dijalankan oleh sekolah melalui pengimplementasian pembelajaran coding (Direktorat Pembinaan PAUD, 2020b)

Penerapan pembelajaran coding di sekolah sudah perlu dikuasai oleh guru sebab coding mendukung kemampuan tingkat tinggi untuk semua orang seperti berpikir kreatif, bertanya, pemecahan masalah dan berpikir kritis yang dianggap penting dalam lingkup kemampuan di abad ke-21 terhadap literasi computational. (Çiftci \& Bildiren, 2020). Computational thinking muncul sebagai keterampilan penting dalam pembelajaran coding. Sebagai keterampilan baru, teori terhadap cara dalam mempraktikkannya pun bervariasi. (Aranda \& Ferguson, 2018). Adapun kegiatan penerapannya memiliki beberapa cara yaitu penerapannya menggunakan komputer atau teknologi informasi dan komunikasi (TIK) disebut coding plugged, kegiatan pembelajaran coding tanpa menggunakan perangkat komputer disebut coding unplugged dan kegiatan pembelajaran coding dengan menggunakan komputer juga tanpa komputer disebut coding plugged-unplugged (Direktorat Pembinaan PAUD, 2020a). Dengan variasi dalam pelaksanaannya artinya semua sekolah dapat melaksanakan program pembelajaran coding yang disesuaikan dengan fasilitas pendukung yang dimiliki sekolah dan inovasi dalam pelaksanaannya sehingga kompetensi computational thinking anak dapat distimulasi sejak dini.

Berdasarkan keunggulan dari pembelajaran coding ini maka pengenalan pembelajaran coding ini perlu diajarkan kemampuan computational thinking sejak dini sebagai kemampuan yang dapat dipergunakan anak dalam kehidupannya sehari-hari untuk menyelesaikan masalah. Menstimulasi kecakapan anak bukan hanya sekedar menggunakan perangkat digital namun kemampuan berpikir secara computational thinking yang memiliki cara memahami, langkah-langkah kinerja otak dalam meningkatkan kognisi anak sejak dini. Dengan berbagai keunggulan pembelajaran coding maka perlu dilakukan pengembangan pembelajaran coding yaitu mengembangkan modul pembelajaran coding. Sebab modul merupakan salah satu bentuk bahan ajar yang dikemas secara utuh dan sistematis, di dalamnya memuat seperangkat pengalaman belajar yang terencana dan didesain untuk membantu peserta didik menguasai tujuan belajar yang spesifik. (Daryanto, 2013). Adapun modul yang dikembangkan berbentuk E-Modul. E- modul Menurut (Winkel, 2009) sebagai bahan ajar sistematis yang penyajian 
metode pengajaran sebagai upaya mencapai tujuan tertentu yang bersifat Self Instruction, Self Contained, Stand Alone, Adaptif, dan User Friendly yang memuat satu materi pembelajaran.

Penelitian sebelumnya menggunakan media dalam kegiatan pembelajaran coding yaitu aplikasi-aplikasi yang cukup besar dengan menggunakan komputer atau smartphone seperti aplikasi Scrach Jr, robot seperti KIBO dan lain-lain (Bers, 2018). Adapun penelitian lain pengembangan modul sains untuk meningkatkan computational thinking anak hanya diperuntukkan untuk anak sekolah dasar (Mensan et al., 2020). Selanjutnya penelitian pengembangan lain berupa media pembelajaran berbentuk lembar kerja anak PAUD untuk meningkatkan computational thinking anak (Maharani et al., 2020).

Sehingga e-modul pembelajaran coding menjadi salah satu alternatif baru dalam dunia pendidikan untuk daerah yang sekolahnya belum melaksanakan pembelajaran coding yang tidak memiliki perangkat komputer sebab kegiatannya berbentuk lembar kerja yang tidak membutuhkan komputer. Selanjutnya modul yang dikembangkan dalam penelitian ini didesain berdasarkan pembelajaran coding berbasis pengenalan budaya Indonesia untuk penanaman karakter identitas diri anak sebagai warga negara dapat dibangun sejak dini. Sesuai dengan (Eliza, 2017) anak-anak semestinya dikenalkan dengan budaya yang sesuai dengan konteks lingkungan anak berkembang, untuk mengembangkan kemampuan berpikir dan mengkonseptualisasikan masalah sosial yang sesuai dengan latar belakang kehidupan mereka sehingga mendapatkan wawasan tentang kehidupan serta pengalaman oranglain.

Maka keunggulan E-Modul ini berupa perkembangnya computational thinking anak serta tertanamnya nilai-nilai budaya dalam diri anak yang menjadi identitas anak. Keberagaman budaya Indonesia menjadi hal penting yang perlu ditanamkan untuk anak sejak usia dini. Wujud pengenalan kebudayaan ini berupa benda-benda yang diciptakan oleh manusia sebagai makhluk yang berbudaya, berupa perilaku dan benda-benda yang bersifat nyata, misalnya pola-pola perilaku, bahasa, peralatan hidup, organisasi sosial, religi, seni, dan lain-lainnya yang kesemuanya ditujukan untuk membantu manusia dalam melangsungkan kehidupan masyarakat Sesuai dengan pendapat (Husni, 2017) benda budaya adalah wujud fisik dari kebudayaan masyarakat yang diwariskan secara turun temurun ke generasi berikutnya. Maka pengenalan benda budaya pada anak dalam E-modul ini berupa pakaian adat, rumah adat dan makanan khas adat Batak dan Minang yang terdekat dengan lingkungan anak.

\section{METODOLOGI}

Jenis penelitian yang digunakan pada penelitian ini adalah penelitian pengembangan (Research and Development). Penelitian ini berfokus pada pengembangan e-modul pembelajaran coding berbasis pengenalan budaya Indonesia. Model desain penelitian pengembangan ini menggunakan penelitian $\mathrm{R} \& \mathrm{D}$ yaitu melalui model desain pembelajaran ADDIE (Analysis-Design-Develop-Implement-Evaluate). Sebagaimana disajikan pada gambar 1.

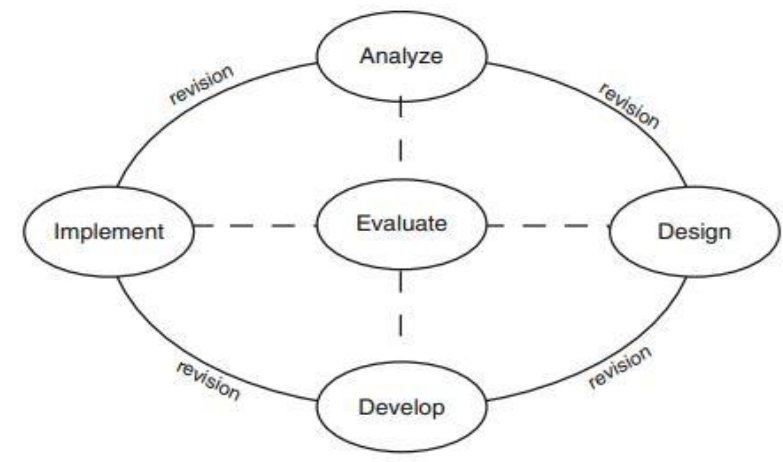

Gambar 1. Desain Modul Pengembangan ADDIE (Branch, 2009) 
Data yang dikumpulkan dari penelitian ini adalah hasil dari validasi e-modul oleh vallidator. Data kelayakan berupa skala Likert. Analisis validitas menggunakan skala likert berdasarkan lembar validasi. Pemberian nilai validitas menggunakan rumus (Azwar, 2012) :

$$
\mathrm{P}=\underline{\mathrm{f}} \times \mathbf{n} \times 100 \%
$$

Setelah persentase diperoleh, dilakukan pengelompokan sesuai kriteria penilaian validitas dengan kriteria sebagaimana disajikan pada tabel 1.

\section{Tabel 1. Kriteria Validitas}

\begin{tabular}{ll}
\hline Interval & \multicolumn{1}{c}{ Kategori } \\
\hline $76 \%-100 \%$ & Sangat Valid \\
$51 \%-75 \%$ & Valid \\
$26 \%-50 \%$ & Kurang Valid \\
$0 \%-25 \%$ & Tidak Valid \\
\hline
\end{tabular}

Setelah divalidasi produk dilakukan dengan uji coba praktikalitas secara terbatas pada guru sebanyak 2 orang di RA Al Amin. Data uji praktikalitas pengguna dalam pengisian angket untuk kepala sekolah dan guru dilakukan dengan menggunakan persentase (\%). Setelah persentase diperoleh, dilakukan pengelompokan sesuai kriteria penilaian praktikalitas dengan kategori sebagaimana pada tabel 2.

\section{Tabel 2. Kriteria}

\begin{tabular}{cl}
\hline Interval & Kategori \\
\hline $76 \%-100 \%$ & Sangat Praktis \\
$51 \%-75 \%$ & Praktis \\
$26 \%-50 \%$ & Kurang Praktis \\
$0 \%-25 \%$ & Tidak Praktis \\
\hline (Sumber :(Sugiyono, 2018))
\end{tabular}

Selanjutnya uji coba efektivitas produk secara terbatas pada subjek yang berjumlah 9 anak dengan kategori 9 anak perempuan di RA Al Amin.

Analisis efektivitas diperoleh dengan cara menghitung anak yang melakukan aktivitas sebagaimana yang terdapat dalam lembar observasi. Hasil perolehan dilihat perbedaan hasil anak melakukan aktivitas pada saat pretes dan postest yang diisi oleh guru kemudian dianalisis dengan menggunakan persentase (\%). Setelah persentase diperoleh, dilakukan pengelompokan sesuai kriteria penilaian efektivitas sebagaimana pada tabel 3 .

Tabel 3. Kriteria Efektivitas E-Modul Pembelajaran Coding berbasis Pengenalan budaya Indonesia untuk meningkatkan Computational Thinking

\begin{tabular}{llc}
\hline \multicolumn{1}{c}{ Kriteria } & Tingkat Keberhasilan & Persentase (\%) \\
\hline Belum Berkembang & Tidak Berhasil & $1-25$ \\
Mulai Berkembang & Kurang Berhasil & $26-50$ \\
Berkembang Sesuai Harapan & Berhasil & $51-75$ \\
Berkembang Sangat Baik & Sangat Berhasil & $76-100$ \\
\hline
\end{tabular}

(Sumber :Kurikulum 2013)

Setelah melakukan uji validitas dilanjutkan uji praktikalitas dan efektivitas secara terbatas produk direvisi kembali sesuai hasil uji coba terbatas agar lebih layak digunakan di uji coba lapangan. Tahap Implement dilakukan dengan uji coba lapangan kepada pendidik berupa uji praktikalitas. Uji praktikalitas dilaksanakan di RA Iththihadul Wathoniyah, RA 
Amanah dan RA Darul Ulum dengan total jumlah guru 20 orang. Selanjutnya uji efektivitas pada kelompok besar dilaksanakan kepada anak kelas B sebanyak 15 anak di RA Iththihadul Wathoniyah. Tahap Evaluate dilakukan untuk pengembangan modul. Evaluasi dilakukan menilai hasil validitas yang telah diisi oleh ahli materi, ahli bahasa dan ahli media. Evaluasi selanjutnya menilai praktikalitas penggunaan modul. Evaluasi efektivitas penggunaan modul dilakukan melalui pretest sebelum implementasi dan posttest di akhir seluruh proses pembelajaran selesai. Hasil keseluruhan menjadi pertimbangan dari produk sudah dapat dipergunakan dengan hasil yang baik dan layak.

\section{HASIL DAN PEMBAHASAN}

\section{Tahap analisis (Analyze)}

Berdasarkan hasil analisis kebutuhan guru dan anak serta analisis kurikulum diperoleh dari hasil wawancara yang dilaksanakan peneliti di RA Ittihadul Wathoniyah, RA Amanah dan RA Darul Ulum pada anak usia 5-6 tahun ditemukan bahwa : 1) sumber belajar yang dimiliki oleh sekolah cukup beragam dan sudah menggunakan bantuan teknologi tdalam melakukan pembelajaran dengan frekuensi penggunaan masih minim 2) sekolah memiliki alat peraga yang dapat menstimulasi pengetahuan anak terhadap budaya namun pendidik belum pernah melaksanakan 3) anak sudah memiliki kemampuan dalam menggunakan teknologi seperti penggunaan HP/Laptop yang diberikan oleh orangtua dirumah seperti kegiatan menonton youtube atau games. 4) anak tertarik dan memiliki bakat dalam kegiatan atau permainan yang membutuhkan kemampuan pola, kegiatan terstruktur sesuai dengan kemampuan anak menguasai games di HP orangtua dan kegiatan saat bermain bebas di sekolah bermain Lego, puzzle dan lain sebagainya.

Hasil angket yang telah disebar diisi oleh 7 sekolah dengan jumlah 9 orang responden yaitu kepala dan pendidik berupa 1) hasil persentasi $100 \%$ pendidik tidak pernah melaksanakan pembelajaran coding 2) pendidik belum pernah mengikuti workshop pembelajaran coding sebesar $77,8 \%$ dan $22,2 \%$ pendidik telah pernah mengikuti workshop pembelajaran coding 3) pendidik tertarik melaksanakan pembelajaran coding sebesar $88,9 \%$ 4) pendidik belum optimal melaksanakan pengenalan budaya terlihat persentase sebesar 77,8 $\%$ dan telah melakukan persentasi sebesar 22,2\% 5) pendidik belum mengetahui pembelajaran coding dapat meningkatkan kompetensi computational thinking anak terlihat persentase sebesar $88,9 \%$.

Pada pelaksanaan analisis kurikulum hasil temuan dilapangan pendidik perlu melakukan penyesuaian tema sesuai prinsip pengembangan tema sebab berdasarkan hasil observasi bahwa pengenalan budaya belum terlaksana optimal penyebabnya 1) guru memilih mengikuti apa yang sudah ada 2) guru tidak mengembangkan kurikulum sesuai dengan lingkungan yang perlu anak ketahui 3) pengembangan kognitif anak sangat perlu distimulus sesuai dengan STTPA usia 5-6 tahun. 4) pengembangan kompetensi computational thinking anak belum tampak pada pembelajaran.

\section{Tahap Desain (Design)}

Tahap desain merupakan bagian tahap perancangan modul pembelajaran coding berbasis pengenalan budaya Indonesia ini dilakukan berdasarkan tahap analisis yang telah dilakukan. Selain itu, tahap perancangan juga bertujuan untuk menyiapkan prototype perangkat pembelajaran berupa modul pembelajaran coding berbasis pengenalan budaya Indonesia. Perancangan kerangka modul pembelajaran coding berbasis pengenalan budaya Indonesia untuk meningkatkan computational thinking anak terdiri atas $3 \mathrm{BAB}$ yaitu $\mathrm{BAB} 1$ pendahuluan, BAB 2 Kegiatan pembelajaran 1, kegiatan pembelajaran 2, BAB 3 evaluasi. Setelah kerangka modul tersusun, selanjutnya dilakukan pengembangan atau menyusun draf modul dengan memperhatikan empat aspek yaitu (1) aspek materi, (2) aspek bahasa (3) aspek media. Tahap ini diawali dengan menentukan desain konten yang ada di dalam modul. Produk yang akan dikembangkan dirumuskan dari Kompetensi Dasar dan Kompetensi Inti 
yang sesuai dengan Kurikulum 2013 kemudian dipadukan dengan teori adapun desain konten dalam modul sebagaimana disajikan pada tabel 4.

Tabel 4. Materi E-Modul Pembelajaran Coding Berbasis Pengenalan Budaya Indonesia.

\begin{tabular}{|c|c|c|c|c|}
\hline No & $\begin{array}{l}\text { Materi } \\
\text { Modul }\end{array}$ & $\begin{array}{c}\text { Tujuan } \\
\text { Pembelajaran }\end{array}$ & Kompetensi CT & Aktivitas CT \\
\hline \multirow[t]{4}{*}{1} & \multirow[t]{4}{*}{$\begin{array}{l}\text { budaya } \\
\text { batak } \\
\text { angkola }\end{array}$} & \multirow{4}{*}{$\begin{array}{l}\text { mengenal dan } \\
\text { mengetahui } \\
\text { tentang rumah } \\
\text { adat batak } \\
\text { angkola, } \\
\text { pakaian adat } \\
\text { batak angkola, } \\
\text { makanan khas } \\
\text { batak angkola }\end{array}$} & Algo & $\begin{array}{l}\text { anak menentukan langkah-langkah yang tepat } \\
\text { menggunakan simbol arah dalam pengenalan rumah } \\
\text { adat batak angkola }\end{array}$ \\
\hline & & & Abstraksi & $\begin{array}{l}\text { anak melingkari bagian-bagian dengan tepat pada } \\
\text { pengenalan pakaian adat batak angkola }\end{array}$ \\
\hline & & & Pola & $\begin{array}{l}\text { anak menentukan pola yang tepat sesuai urutan pada } \\
\text { pengenalan bagian pakaian adat batak angkola }\end{array}$ \\
\hline & & & dek & $\begin{array}{l}\text { anak mampu menentukan jumlah yang tepat pada } \\
\text { bagian melengkapi jumlah pada kegiatan pengenalan } \\
\text { makanan khas batak angkola }\end{array}$ \\
\hline \multirow[t]{4}{*}{2} & \multirow[t]{4}{*}{$\begin{array}{l}\text { budaya } \\
\text { minang }\end{array}$} & \multirow{4}{*}{$\begin{array}{l}\text { mengenal dan } \\
\text { mengetahui } \\
\text { tentang rumah } \\
\text { adat minang, } \\
\text { pakaian adat } \\
\text { minang, } \\
\text { makanan khas } \\
\text { minang }\end{array}$} & $\mathrm{Alg}$ & $\begin{array}{l}\text { anak menentukan langkah-langkah yang tepat } \\
\text { menggunakan simbol arah dalam pengenalan rumah } \\
\text { adat minang }\end{array}$ \\
\hline & & & Abstraksi & $\begin{array}{l}\text { anak melingkari bagian-bagian dengan tepat pada } \\
\text { pengenalan pakaian adat batak angkola }\end{array}$ \\
\hline & & & Pola & $\begin{array}{l}\text { anak menentukan pola yang tepat sesuai urutan pada } \\
\text { pengenalan bagian pakaian adat minang }\end{array}$ \\
\hline & & & GекU1 & $\begin{array}{l}\text { Anak mampu menentukan jumlah yang tepat pada } \\
\text { bagian melengkapi jumlah pada kegiatan pengenalan } \\
\text { makanan khas minang }\end{array}$ \\
\hline
\end{tabular}

Sumber : (BBC, 2018; Departemen Pendidikan dan Kebudayaan, 1986; Direktorat Pembinaan PAUD, 2018; Parsadaan Marga Harahap Dohot Anakboruna, 1993)

Modul ini didesain dengan pengenalan budaya Batak dan Budaya Minang berupa makanan khas, pakaian adat dan rumah adat yang selanjutnya aktivitas kegiatan di evaluasi menggunakan pembelajaran coding untuk mengembangan keterampilan computational thinking. Keterampilan yang dapat dikembangkan melalui computational thinking menurut BBC Bitesize, 2018 dalam (Kong, Siu-Cheung \& Abelson, 2019) yaitu a) Decomposition, memecah masalah atau sistem yang kompleks menjadi bagian-bagian yang lebih kecil dan lebih mudah dikelola b) Pattern recognition, mencari persamaan diantara masalah c) Abstraction, fokus pada informasi penting dan mengabaikan bagian kecil-kecil yang tidak relevan d) Algorithms, mengembangkan langkah demi langkah penyelesaian masalah, atau mengikuti aturan untuk memecahkan masalah. Computational Thinking yang dikembangkan sebagaimana pada tabel 5. Gambaran kegiatan Kompetensi algoritma dan dekomposisi sebagaimana pada gambar 2 dan 3.

Tabel 5. Computational Thinking

\begin{tabular}{ll}
\hline Kompetensi CT & Defenisi Operasional \\
\hline Dekomposisi & $\begin{array}{l}\text { Memecahkan masalah yang rumit atau sistem menjadi bagian yang lebih kecil } \\
\text { dan mudah dikerjakan }\end{array}$ \\
Abstraksi & $\begin{array}{l}\text { Mengidentifikasi dan memperhatikan inti masalah yang lebih tepat untuk } \\
\text { memahami suatu tugas atau masalah dengan lebih baik }\end{array}$ \\
Algoritma & $\begin{array}{l}\text { Menyajikan solusi dalam memecahkan suatu tugas atau masalah sebagai suatu } \\
\text { instruksi langkah demi langkah (step by step) }\end{array}$ \\
Pengenalan Pola & $\begin{array}{l}\text { Mengidentifikasi pola berdasarkan karakteristik, proses, atau hubungan dalam } \\
\text { suatu tugas atau masalah untuk mengembangkan pengetahuan yang } \\
\text { terstruktur dan memecahkan suatu tugas yang sama atau masalah dengan } \\
\text { strategi yang sama }\end{array}$ \\
\hline & (Sumber :(BBC, 2018; Hunsaker, 2017; Kong, Siu-Cheung \& Abelson, 2019))
\end{tabular}




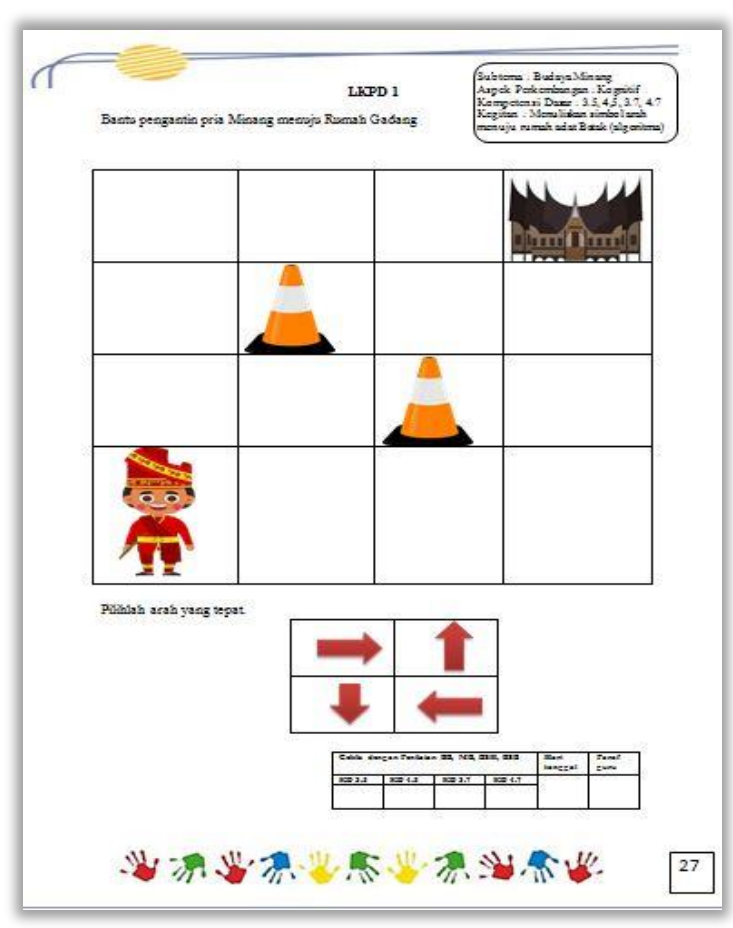

Gambar 2. Kegiatan kompetensi algoritma

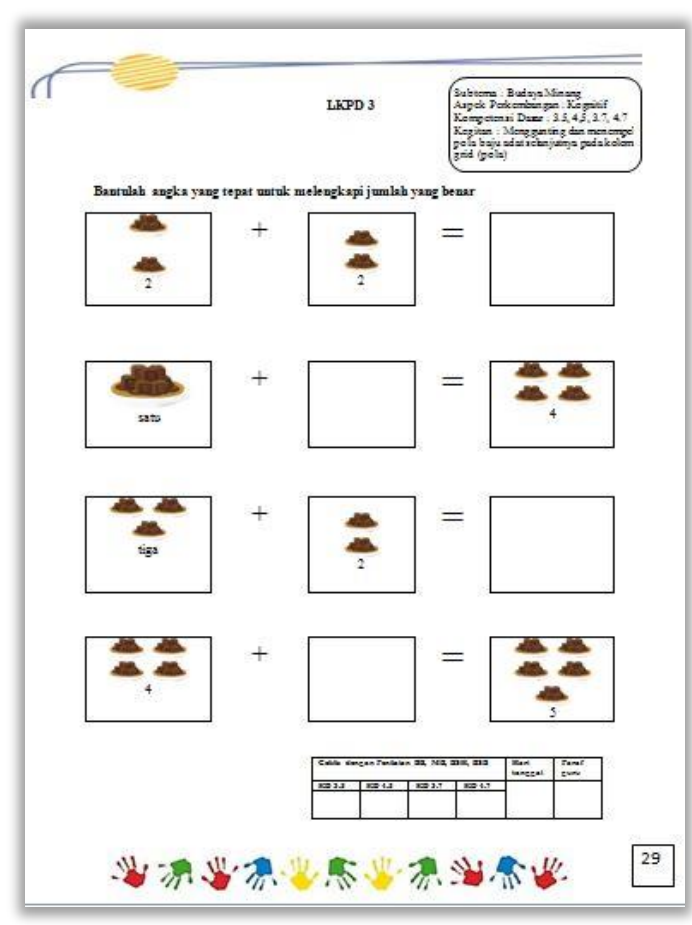

Gambar 3. Kegiatan kompetensi dekomposisi

\section{Tahap pengembangan (Develop)}

Tahap pengembangan dilakukan untuk menguji kelayakan isi modul pembelajaran yang dikembangkan. Adapun kegiatan-kegiatan yang dilakukan dalam tahap ini, yaitu uji validitas modul, uji praktikalitas modul dan uji efektivitas modul. Uji praktikalitas modul dilaksanakan setelah modul divalidasi oleh para pakar atau ahli. Sementara itu, uji efektivitas modul juga dilaksanakan dalam proses pembelajaran dengan kelompok kecil.

\section{Uji validitas}

Uji validitas dilakukan untuk melihat kevalidan modul yang sudah dirancang sebelum diujicobakan dalam pembelajaran. Validasi modul pembelajaran dilakukan oleh 3 orang ahli, yakni satu pakar bahasa, satu pakar materi anak usia dini, satu pakar media. Instrumen yang digunakan dalam memvalidasi modul pembelajaran tersebut berbentuk angket. Angket validasi ini terdiri atas aspek kelayakan materi, aspek kelayakan bahasa dan aspek kelayakan desain media dengan total 43 butir pernyataan dengan teknik pengukuran menggunakan skala likert sebagaimana disajikan pada tabel 6.

Berdasarkan analisis yang dilakukan pada angket validasi modul, maka modul pembelajaran yang dikembangkan mencapai tingkat $87 \%$ kategori sangat valid. Tingkat pencapaian atau persentase masing-masing aspek terdapat pada gambar 4

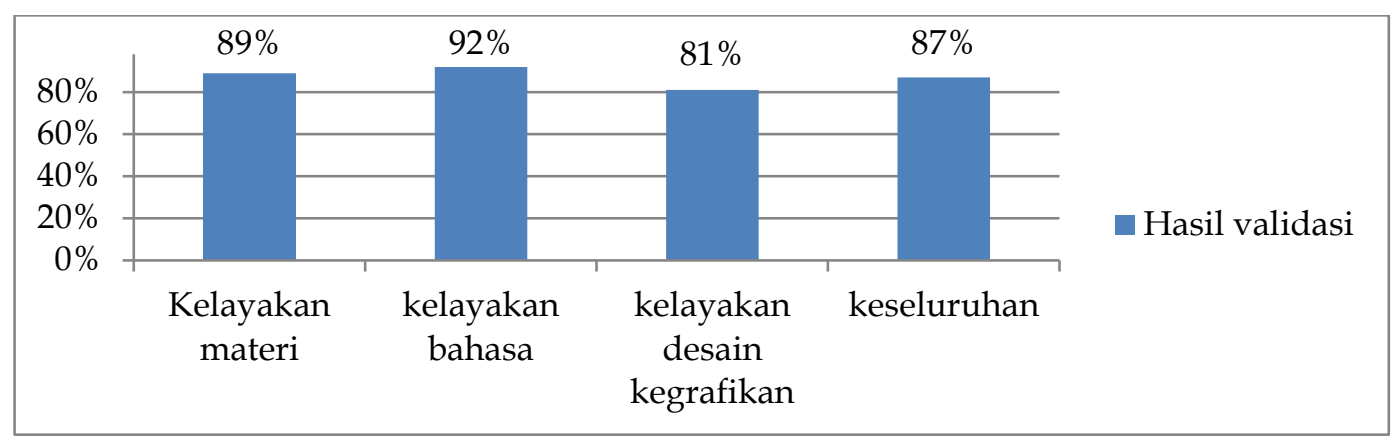

Gambar 4. Hasil persentase kelayakan validitas modul 
Tabel 6. Kisi-Kisi Instrumen Validitas E-Modul

\begin{tabular}{|c|c|c|c|}
\hline \multicolumn{2}{|r|}{ NoAspek Indikator penilaian } & Nomor pertanyaan & Jumlah \\
\hline & Kesesuaian materi & $1,2,3$ & 3 \\
\hline & Keakuratan materi & 4,5 & 2 \\
\hline & Materi Kemutakhiran materi & 6,7 & 2 \\
\hline & Teknik penyajian & $8,9,10$ & 3 \\
\hline & Kelengkapan penyajian & \multicolumn{2}{|c|}{$11,12,13,14,15,16,17,188$} \\
\hline & Lugas & 19,20 & 3 \\
\hline \multirow{4}{*}{2} & Komunikatif & 21 & 1 \\
\hline & Dialogis dan interaktif & 22,23 & 2 \\
\hline & a ${ }^{\mathrm{C}}$ Kesesuaian dengan perkembangan an & $k 24,25$ & 2 \\
\hline & Kesesuaian dengan Kaidah Bahasa & 26,27 & 2 \\
\hline & Penggunaan istilah, simbol, atau ikon. & 28,29 & 2 \\
\hline & Konsistensi & $30,31,32$ & 3 \\
\hline & Format & 33 & 1 \\
\hline & Organisasi & 34,35 & 2 \\
\hline & Media Daya Tarik & $36,37,38$ & 3 \\
\hline & Bentuk dan ukuran huruf & 39,40 & 2 \\
\hline & Ruang kosong & 41,42 & 2 \\
\hline
\end{tabular}

\section{Uji praktikalitas pada uji coba terbatas}

Uji coba terbatas dilaksanakan pada bulan November 2021 di RA Al Amin dengan jumlah guru kelas 2 orang. Hasil kelayakan uji coba praktikalitas modul disajikan pada tabel 7.

Tabel 7. Hasil kelayakan uji coba praktikalitas modul

\begin{tabular}{|c|c|c|c|c|}
\hline No & Jumlah Responden & Jumlah butir & Skor Total & Skor Maksimal \\
\hline 1 & 2 Guru & 17 & 120 & 136 \\
\hline \multicolumn{4}{|c|}{ Total Persentase kepraktisan } & $87,5 \%$ \\
\hline \multicolumn{4}{|c|}{ Kategori kepraktisan } & Sangat praktis \\
\hline
\end{tabular}

Berdasarkan analisis yang dilakukan pada angket praktikalitas modul pada aspek kemudahan dalam penggunaan dan waktu yang digunakan dengan jumlah butir 17 butir pernyataan kemudian dilakukan penskoran dengan menggunakan rumus persentase, maka modul pembelajaran yang dikembangkan khususnya pada uji coba aspek praktikalitas mencapai $87,5 \%$ dengan kategori sangat praktis.

\section{Uji efektivitas pada uji coba terbatas}

Uji coba terbatas dilaksanakan pada bulan November 2021 di RA Al Amin di kelas B1 pada kelompok kecil dengan jumlah anak sebanyak 9 orang anak. Berdasarkan penggunaan modul pembelajaran coding berbasis pengenalan budaya Indonesia untuk meningkatkan computational thinking anak diperoleh data pretest sebesar $40 \%$. Setelah dilaksanakan treatment kemudian dilaksanakan postest dengan perolehan sebesar 78\%. Adapun peningkatan kemampuan anak dalam penggunaan modul dapat dilihat pada grafik pada gambar 5 .

Berdasarkan grafik pada gambar 4, hasil pengamatan pada lembar aktivitas kegiatan pretes dan posttes untuk mengetahui tingkat efektivitas pada uji coba lapangan penggunaan modul pembelajaran coding berbasis pengenalan budaya Indonesia untuk meningkatkan computational thinking anak diperoleh peningkatan signifikan pada hasil postest sebesar $88 \%$ dengan kategori sangat efektif. 


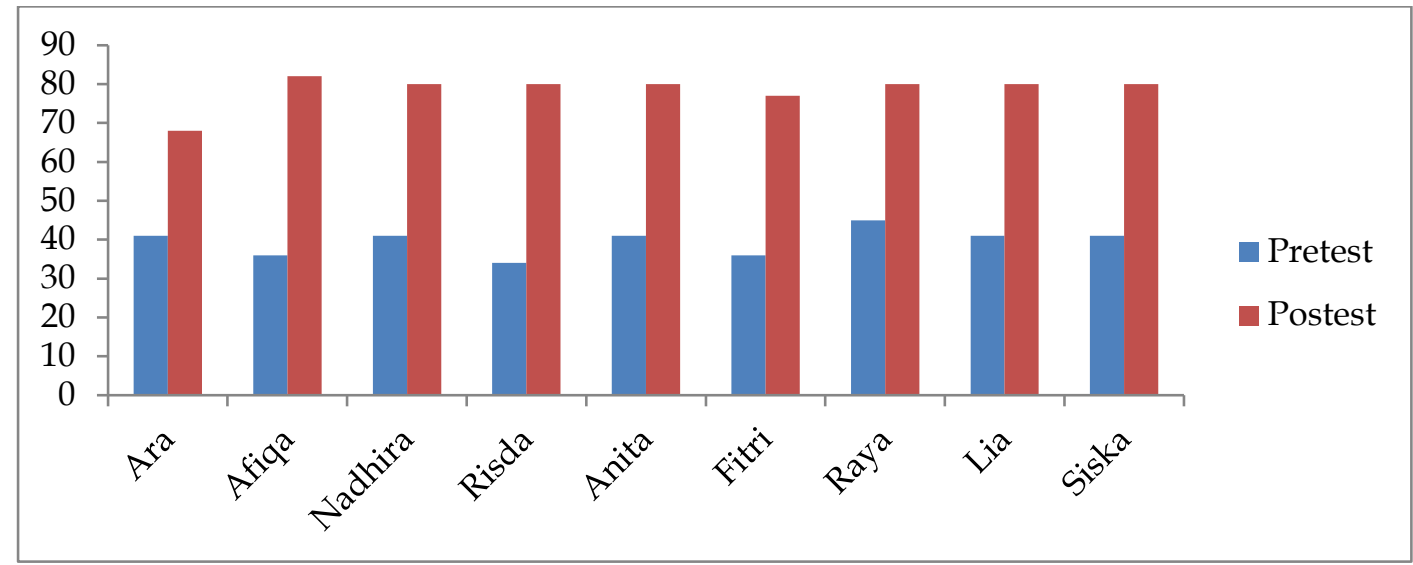

Gambar 5. Hasil uji efektivitas pada uji coba terbatas

\section{Tahap Implementasi (Implement)}

Pada tahap implementasi, produk ini diimplementasikan dengan menggunakan revisi dari produk modul yang sudah dinyatakan layak oleh ahli dan diuji coba kepada anak, selanjutnya pendidik menilai modul untuk mengetahui kelayakan modul ketika digunakan oleh pengguna dan respon pengguna setelah menggunakan modul pembelajaran tersebut. Implementasi modul pembelajaran coding berbasis pengenalan budaya Indonesia dilaksanakan pada tanggal 15 November-19 November 2021 di RA Iththihadul Wathoniyah pada kelas B dengan jumlah anak 15 anak. Kemudian penilai modul pembelajaran coding berbasis pengenalan budaya Indonesia juga dinilai oleh guru-guru dari RA Iththihadul Wathoniyah sebanyak 4 orang, RA Amanah sebanyak 6 orang, RA Darul Ulum sebanyak 7 orang dan RA Raihan sebanyak 3 orang dengan total jumlah guru sebanyak 20 guru.

\section{Uji praktikalitas pada uji lapangan}

Berdasarkan hasil penilaian uji praktikalitas guru RA Iththihadul Wathoniyah, RA Amanah, RA Darul Ulum dan RA Raihan dengan total guru sebanyak 20 orang. Berdasarkan tabel diatas diperoleh hasil uji praktikalitas pada aspek kemudahan dalam penggunaan dan waktu yang digunakan sebesar 89,7\% dengan arti penggunaan modul pembelajaran coding berbasis pengenalan budaya untuk meningkatkan computational thinking anak usia 5-6 tahun dikategorikan sangat praktis.

Tabel 8. Hasil uji praktikalitas uji coba lapangan

\begin{tabular}{|c|c|c|c|}
\hline No & Jumlah Responden Jumlah butir & Skor Total & Skor Maksimal \\
\hline 1 & 20 Guru & 1221 & 1360 \\
\hline \multicolumn{3}{|c|}{ Total Persentase kepraktisan } & $89,7 \%$ \\
\hline \multicolumn{3}{|c|}{ Kategori kepraktisan } & Sangat praktis \\
\hline
\end{tabular}

\section{Uji efektivitas pada uji coba lapangan}

Data analisis aktivitas belajar anak diperoleh dengan cara menghitung hasil penilaian pada lembar kerja anak dalam e-modul pembelajaran coding berbasis pengenalan budaya Indonesia untuk meningkatkan computational thinking anak pada uji kelompok besar dikelas B sebanyak 15 orang anak, penilaian menggunakan format penugasan dengan rubrik penilaian yang telah ditetapkan pada setiap lembar kerja anak. Berdasarkan penggunaan e-modul pembelajaran coding berbasis pengenalan budaya Indonesia untuk meningkatkan computational thinking anak diperoleh data pretest sebesar 55\%. Setelah dilaksanakan treatment kemudian dilaksanakan postest dengan perolehan sebesar 88\%. Adapun peningkatan kemampuan anak dalam penggunaan modul dapat dilihat pada grafik pada gambar 6. 


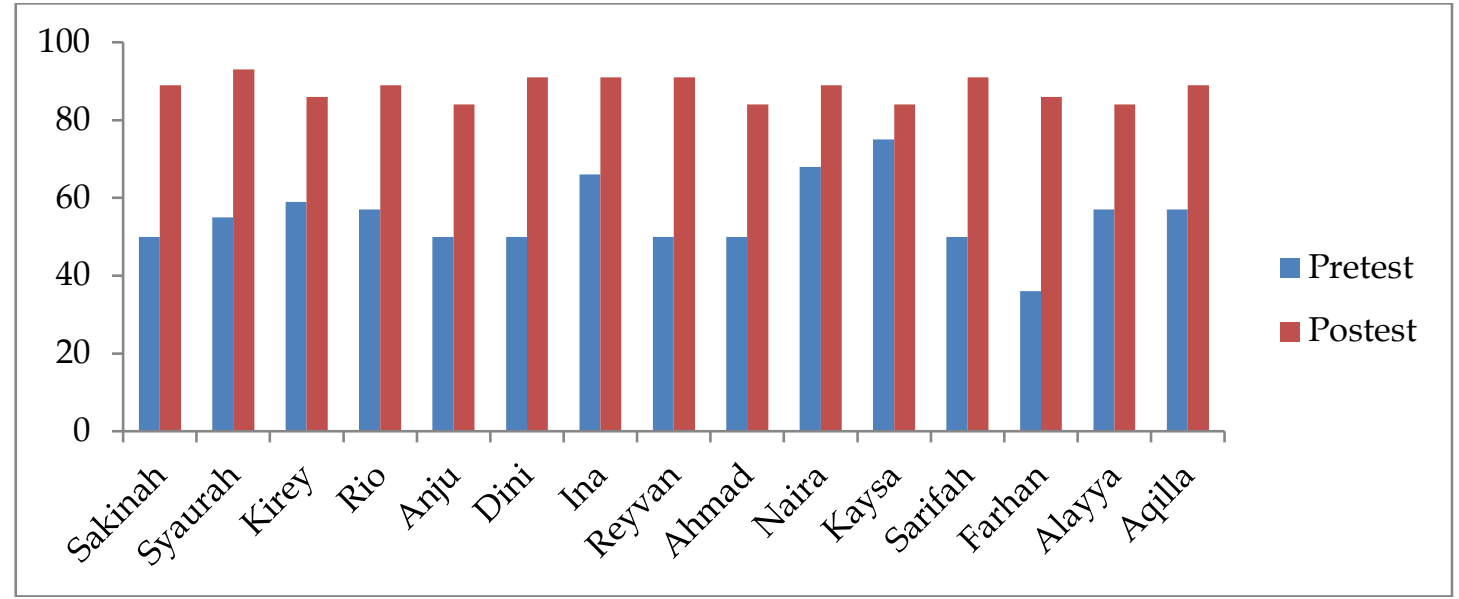

Gambar 6. Hasil uji efektivitas pada uji lapangan

Berdasarkan gambar 6 grafik pada hasil pengamatan pada lembar aktivitas kegiatan pretes dan posttes untuk mengetahui tingkat efektivitas penggunaan e-modul pembelajaran coding berbasis pengenalan budaya Indonesia untuk meningkatkan computational thinking anak maka diperoleh peningkatan signifikan pada hasil postest sebesar $88 \%$ dengan kategori sangat efektif.

\section{Tahao Evaluasi (Evaluate)}

Pada tahap evaluasi hasil dari uji validitas, praktikalitas dan efektivitas disatukan untuk melihat hasil keseluruhan pelaksanaan dalam penggunaan produk. Pada uji validitas produk hasil evaluasi diperoleh berdasarkan lembar penilaian dari dosen ahli terhadap modul pembelajaran coding berbasis pengenalan budaya Indonesia anak usia dini di Taman Kanakkanak. Berdasarkan hasil keseluruhan validitas yaitu sangat valid dengan revisi materi, bahasa dan desain media dilakukan untuk perbaikan media lebih baik lagi. Adapun evaluasi berupa penggantian gambar dalam modul yang beberapa item harus asli seperti gambar dari rumah adat, makanan khas agar dalam proses pengenalan lebih memudahkan anak mengenalnya serta bahasa yang lebih sederhana.

Evaluasi pada uji praktikalitas modul pada uji coba kelompok kecil sebanyak 2 orang pendidik menyatakan modul layak digunakan dengan revisi dengan hasil persentase praktikalitas sangat praktis. Selanjutnya hasil uji praktikalitas modul pada uji coba lapangan sebanyak 20 orang pendidik menyatakan modul layak digunakan dengan revisi dengan hasil persentase praktikalitas sangat praktis. Evaluasi yang perlu dilakukan berupa penjelasan instruksi kegiatan perlu dicantumkan dan disederhanakan penjelasannya.

Pada uji efektivitas produk pada pelaksanaan pretes dan postes pada kelompok kecil dengan jumlah 9 orang anak pada kegiatan evaluasi aktivitas anak diperoleh hasil peningkatan kemampuan anak dalam mengenal budaya Indonesia dan computational thinking anak berkembang sesuai hasil lembar pengamatan anak yang menyatakan hasil persentase sangat efektif. Selanjutnya hasil uji efektivitas produk pada pelaksanaan pretes dan postes pada uji lapangan dengan jumlah 15 orang anak pada kegiatan evaluasi aktivitas anak diperoleh hasil peningkatan kemampuan anak dalam mengenal budaya Indonesia dan computational thinking anak berkembang sesuai hasil lembar pengamatan anak yang menyatakan hasil persentase sangat efektif. Evaluasi yang dapat dilaksanakan dalam kegiatan uji praktikalitas berupa tingkat kesulitan dari lembar kerja perlu memiliki rentang rendah, sedang dan sulit agar stimulasi yang dilaksanakan memaksimalkan perkembangan anak. 


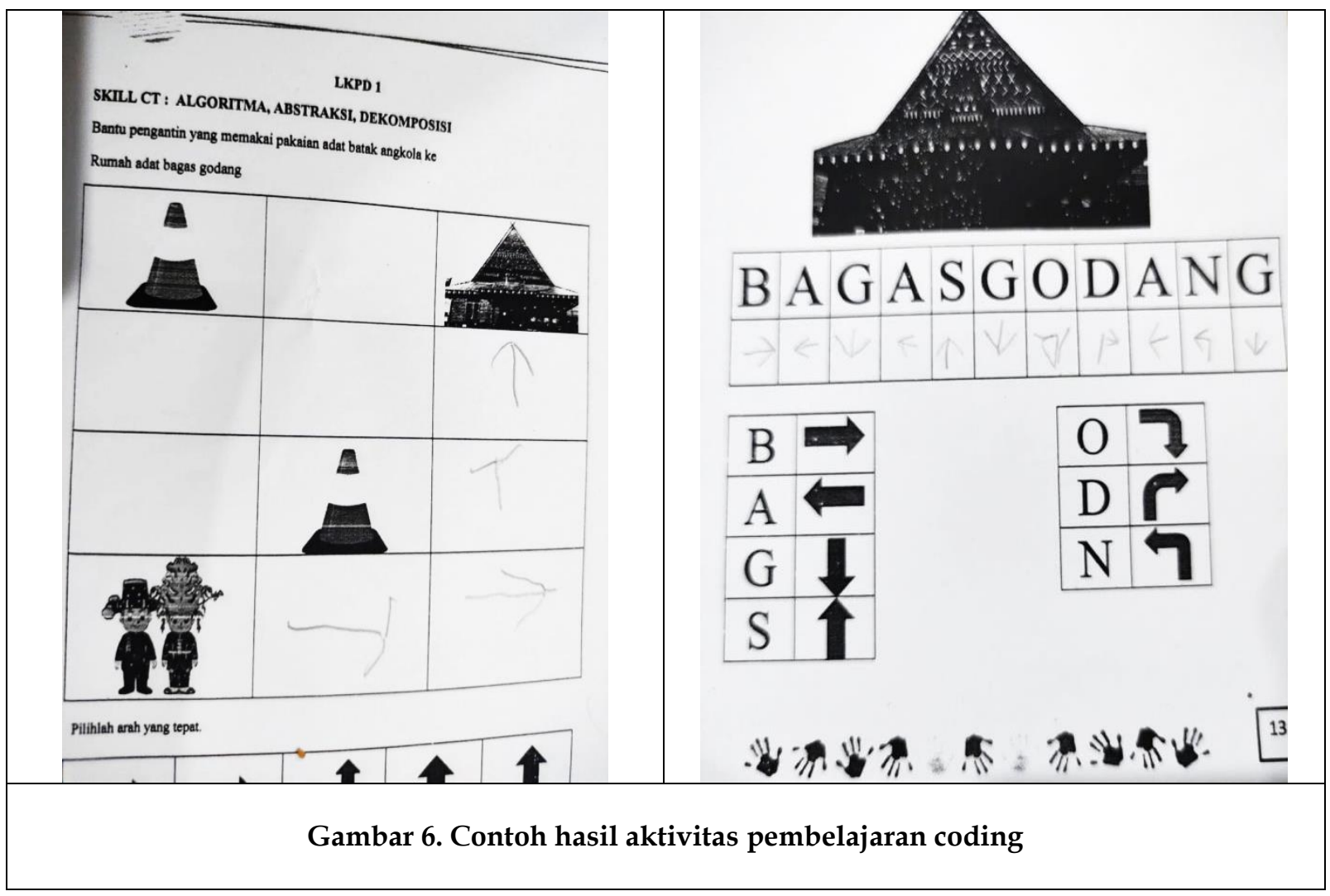

\section{Pembahasan}

Sejalan dengan Permendibud No 137 dan 146 tentang Standar Tingkat Pencapaian Perkembangan Kognitif Anak usia 5-6 tahun dan Pedoman Penyusunaan Kurikulum 2013 PAUD. Pada penyusunaan Kurikulum 2013 PAUD makna dan prisip penyusunaan Kurikulum 2013 PAUD adalah (1) Berpusat pada anak (2) Kurikulusm dikembangkan secara kontekstual (3) Mencakup semua dimensi kompetensi dan program pengembangan (4) Program pengembangan sebagai dasar pembentukan kepribadian anak (5) Memperhatikan tingkat perkembangan anak (6) Mempertimbangkan cara anak belajar (7) Holistik-integratif (8) Belajar melalui bermain (9) Memberi pengalaman belajar (10) Memperhatikan dan melestarikan karakteristik sosial budaya. Berdasarkan analisis kurikulum maka peneliti mengembangkan produk sesuai dengan prinsip pengembangan kurikulum berupa memperhatikan dan melestarikan karakteristik sosial budaya sebagai tema yang menjadi fokus dalam pengembangan pada pembelajaran coding untuk meningkatkan computational thinking anak dalam bentuk modul.

Berdasarkan hasil penelitian yang telah dipaparkan maka dapat kita simpulkan produk yang telah di desain kemudian dikembangankan untuk diuji kelayakannya. Hasil pengembangan yang baik ditentukan dari kualitas produk hasil pengembangan. Menurut (Nieveen, 1999) kualitas hasil pengembangan pada penelitian pengembangan ditentukan oleh beberapa kriteria yaitu validity (validitas), practicality (kepraktisan), effectiveness (keefektifan). Maka produk yang dikembangkan selanjutnya divalidasi oleh pakar untuk menguji kelayakan empat aspek yaitu (1) aspek materi, (2) aspek bahasa (3) aspek desain media. Untuk menguji validitas dapat digunakan penilaian dari validator ahli (Sugiyono, 2018). Pada hasil uji validitas oleh ahli yaitu ahli materi, ahli bahasa dan ahli media diperoleh hasil produk awal yang dikembangkan sangat valid dengan persentasi kevalidan $89 \%$ yang artinya produk yang dikembangkan untuk tahap awal layak digunakan dengan mengikuti saran atau catatan dari ahli untuk melakukan revisi. Setelah melakukan uji validitas peneliti kemudian melaksanakan uji coba terbatas untuk mengetahui praktikalitas dan efektivitas dari produk yang dikembangkan. 
Kepraktisan ditentukan dari hasil penilaian pengguna atau pemakai. Kepraktisan mengacu pada sejauh mana pengguna (dan ahli lainnya) mempertimbangkan intervensi menarik dan dapat digunakan dalam kondisi normal. Produk hasil pengembangan disimpulkan praktis jika guru (ahli lainnya) mempertimbangkan produk mudah digunakan oleh guru dan siswa. Menurut (Daryanto, 2013) uji coba yang dimaksud adalah mengujicobakan draf modul pembelajaran coding berbasis pengenalan budaya Indonesia yang telah divalidasi kepada beberapa orang sampel sasaran belajar. Kegiatan ini dilakukan untuk mengetahui sejauh mana manfaat, kemudahan penggunaan oleh guru. Berdasarkan hasil penelitian melalui angket praktikalitas modul pada aspek kemudahan dalam penggunaan dan waktu yang digunakan diperoleh hasil sangat praktis dalam penggunaannya. Sesuai dengan pendapat (Prastowo, 2015) Modul adalah bahan ajar yang disusun secara sistematis, dengan bahasa yang mudah dipahami sesuai tingkat pengetahuan dan perkembangan siswa sehingga mereka dapat belajar mandiri. Serta format modul ini terdiri atas tiga bagian yaitu pendahuluan, pembelajaran dan evaluasi yang keseluruhannya telah memenuhi elemen modul (Daryanto, 2013). Maka modul pembelajaran yang dikembangkan khususnya pada uji coba aspek praktikalitas mencapai 87,5\% dengan kategori sangat praktis. Hasil uji praktikalitas pada pelaksanaan uji coba lapangan sebesar $89,7 \%$ dengan arti penggunaan modul pembelajaran coding berbasis pengenalan budaya untuk meningkatkan computational thinking anak usia 5-6 tahun dikategorikan sangat praktis.

Efektivitas adalah pengukuran keberhasilan dalam pencapaian tujuan yang telah ditentukan. (Nieveen, 1999) efektivitas merujuk pada sejauh mana pengalaman dan hasil intervensi konsisten dengan tujuan yang dimaksud. Keefektifan modul dalam penelitian ini dilihat melalui respon guru terhadap penggunaannya. Indikator suatu modul dikatakan efektif apabila modul mampu membangkitkan motivasi kepada siswa untuk belajar dan aktivitas modul bersesuaian dengan langkah-langkah pembelajaran yang digunakan. Pada kegiatan pretest dan posttes untuk mengetahui tingkat efektivitas pada uji coba lapangan penggunaan modul pembelajaran coding berbasis pengenalan budaya Indonesia untuk meningkatkan computational thinking anak maka diperoleh peningkatan signifikan pada hasil postest sebesar $88 \%$ dengan kategori sangat efektif. Selanjutnya pada kegiatan uji lapangan kegiatan pretes dan posttes pada uji efektivitas penggunaan modul pembelajaran coding berbasis pengenalan budaya Indonesia untuk meningkatkan computational thinking anak maka diperoleh peningkatan signifikan pada hasil postest sebesar $88 \%$ dengan kategori sangat efektif.

Hal ini sesuai dengan teori Wing (2008) yang mendefinisikan computational thinking sebagai : (1) Konseptualisasi, bukan proses pengembangan bahasa pemrograman. Oleh karena itu, siswa diminta untuk menggunakan tingkat berpikir abstrak yang berbeda. Pemikiran komputasional tidak terbatas pada penggunaan komputer untuk belajar (2) Proses logis lebih diutamakan daripada tindakan berulang dari operasi mekanis. Oleh karena itu, pemikiran berbantuan komputer memberi orang lebih banyak fleksibilitas dalam menggunakan keterampilan mereka. (3) Pemikiran manusia, bukan mode perhitungan komputer. Dengan kata lain, berpikir komputasional adalah cara untuk memecahkan masalah manusia, bukan hanya meniru cara berpikir komputer. Karena manusia lebih pintar dan lebih cerdas daripada komputer (4) Kombinasi pemikiran matematika dan teknik memperluas dasar-dasar matematika; (5) Memecahkan masalah kehidupan dalam kehidupan sehari-hari adalah produk pemikiran siap pakai yang membantu Anda mengelola perilaku, berkomunikasi, dan berinteraksi kepada orang lain. (6) Keterampilan dasar kehidupan sehari-hari, bukan filosofi abstrak.

Selanjutnya Bell \& Bell (2018) menjelaskan ketika computational thinking diajarkan secara umum, pendidik dapat mengajarkan bagaimana: a) menjelaskan masalah, b) mengidentifikasi detail penting yang diperlukan untuk menyelesaikan masalah itu, c) memecah masalah menjadi langkah-langkah kecil dan logis, d) gunakan langkah-langkah ini untuk membuat proses (algoritma) yang memecahkan masalah, e) evaluasi proses ini. Maka penerapan teori 
melalui sebuah modul cukup efektif, karena modul berfungsi sebagai bahan ajar yang mampu menjelaskan materi pembelajaran dengan baik dan mudah dipahami oleh peserta didik sesuai dengan tingkat pengetahuan dan usia. (Prastowo, 2015). Modul dilengkapi kegiatan aktivitas berbasis coding unplugged di dalam modul berbentuk lembar kerja anak yang terintegrasi dengan kurikulum sehingga meningkatkan keterampilan coding dasar anak-anak prasekolah (Metin, 2020).

Kombinasi penggunaan simbol-simbol budaya Indonesia berupa rumah adat, pakaian adat, dan makanan khas dari Batak Angkola dan Minangkabau menambah variasi menarik dalam modul pembelajaran coding. Melalui budaya, Pendidikan berbasis keunggulan budaya lokal adalah pendidikan yang memanfaatkan keunggulan lokal dalam aspek ekonomi, budaya, bahasa, teknologi informasi dan komunikasi, ekologi dan lain-lain, yang semuanya bermanfaat bagi pengembangan kompetensi peserta didik (Asmani, 2012). Sebab budaya merupakan karya masyarakat yang dapat menghasilkan teknologi dan kebudayaan kebendaan atau kebudayaan jasmaniah yang diperlukan oleh manusia untuk menguasai alam sekitarnya agar kekuatan serta hasilnya dapat diabadikan untuk keperluan masyarakat. (Ranjabar, 2006).

\section{SIMPULAN}

Sebab pengembangan produk e-modul ini memberikan peningkatan terhadap materi pembelajaran dapat dicapai, peningkatan kompetensi anak khususnya aspek kognitif anak memiliki peningkatan karena kognisi anak distimulasi cara berpikir yang solutif dalam kehidupan anak. Hal ini sejalan dengan hasil penelitian ini yaitu pertama, pengembangan emodul ini dapat dikatakan sangat valid. Kedua, pengembangan e-modul ini dapat dikatakan sangat praktis. Ketiga, pengembangan e-modul pembelajaran coding berbasis pengenalan budaya Indonesia untuk meningkatkan computational thinking anak dapat dikatakan sangat efektif.

\section{UCAPAN TERIMA KASIH}

Terimakasih kepada seluruh dosen jurusan S2 PAUD UNP yang telah membimbing selama studi dan terimakasih kepada pembimbing saya Dr. Delfi Eliza yang telah membimbing penelitian saya dalam penulisan dan pelaksanaan penelitian. Terimakasih kepada beberapa sekolah di Kota Padangsidimpuan terkhusus RA Ittihadul Wathoniyah Kota Padangsidimpuan Provinsi Sumatera Utara telah menerima dan mendukung saya untuk melakukan penelitian dan mengizinkan melakukan beberapa perubahan dan perbaikan pada satuan pendidikan ini.

\section{DAFTAR PUSTAKA}

Aranda, G., \& Ferguson, J. P. (2018). Unplugged Programming: The future of teaching computational thinking? Pedagogika, 68(3), 279-292. https:// doi.org/10.14712/23362189.2018.859

Asmani, J. M. (2012). Pendidikan Berbasis Keunggulan Lokal. Diva Press.

Azwar, S. (2012). Reliabiltas dan Validitas (Edisi 4). Pustaka Pelajar.

Barron, B., Cayton-Hodges, G., Copple, C., Darling-Hammond, L., \& Levine, M. (2011). Take a giant step: A blueprint for teaching young children in a digital age. The Joan Ganz Cooney Center at Sesame Workshop and Stanford University, 16(11), 1-54.

BBC. (2018). Introduction to computational thinking. BBC.

Bell, J., \& Bell, T. (2018). Integrating computational thinking with a music education context. Informatics in Education, 17(2), 151-166. https:// doi.org/10.15388/infedu.2018.09

Bers, M. U. (2018). Coding, playgrounds and literacy in early childhood education: The development of KIBO robotics and ScratchJr. IEEE Global Engineering Education 
EDUCON,

2018-April,

2094-2102.

https://doi.org/10.1109/EDUCON.2018.8363498

Bers, M. U. (2020). Coding as a playground: Programming and computational thinking in the early childhood classroom. In Coding as a Playground: Programming and Computational Thinking in the Early Childhood Classroom (pp. 1-229). https:// doi.org/10.4324/9781003022602-101

Branch, R. M. (2009). Instructional Design: The ADDIE Approach. Department of Educational Psychology and Instructional Technology University Of Georgia. https://doi.org/10.1007/978-0-387-09506-6

Campbell \& Walsh, C. (2017). Introducing the "new" digital literacy of coding in the early years. Practical Literacy: The Early \& Primary Years, 22(3), 10-12.

Çiftci, S., \& Bildiren, A. (2020). The effect of coding courses on the cognitive abilities and problem-solving skills of preschool children. Computer Science Education, 30(1), 3-21. https://doi.org/10.1080/08993408.2019.1696169

Daryanto. (2013). Menyusun Modul Bahan Ajar Untuk Persiapan Guru Dalam Mengajar. Gava Media.

Departemen Pendidikan dan Kebudayaan. (1986). Pakaian Adat Tradisional Daerah Sumatera Barat.

Direktorat Pembinaan PAUD. (2018). Kerangka Dasar dan Struktur Kurikulum 2013 PAUD (Issue 021).

Direktorat Pembinaan PAUD. (2020a). Coding, Konsep Pembelajaran Ptk, Serta Peran Tua, Orang Komunitas, Mitra D A N Penerapan, Dalam Coding, Pembelajaran Paud, D I Satuan.

Direktorat Pembinaan PAUD. (2020b). Pengintegrasian Pembelajaran Coding dalam Kurikulum Tingkat Satuan Pendidikan (KTSP) dan Pengembangan RPP di Satuan PAUD.

Eliza, D. (2013). Penerapan Model Pembelajaran Kontekstual Learning (CTL) Berbasis Centra di Taman Kanak-kanak. Pedagogi UNP, XIII(No. 2).

Eliza, D. (2017). Pengembangan Model Pembelajaran Karakter Berbasis Cerita Tradisional Minangkabau Untuk Anak Usia Dini. Pedagogik, 3, 153-163.

Farida Mayar. (2019). Urgensi Profesionalisme Guru Paud Dalam Mengembangan Kreativitas Anak Usia Dini. Jurnal Pendidikan Tambusai, 3, 1113-1119.

Hunsaker, E. (2017). Computational Thinking (pp. 1-28).

Husni, R. (2017). Pakaian Pengantin Perempuan dalam Tradisi Manjalang di Kelurahan Balai Gadang Kecamatan Koto Tangah Kota Padang. Tesis UNP.

Kong, Siu-Cheung \& Abelson, H. (2019). Computational Thinking Education. In Computational Thinking Education. Springer Open. https:// doi.org/10.1007/978$\underline{981-13-6528-7}$

Maharani, S., Nusantara, T., As'ari, A. R., \& Qohar, A. (2020). Computational Thinking: Media Pembelajaran CSK (CT-Sheet for Kids) dalam Matematika PAUD. Jurnal Obsesi : Jurnal Pendidikan Anak Usia Dini, 5(1), 975-984. https://doi.org/10.31004/obsesi.v5i1.769

Mensan, T., Osman, K., \& Majid, N. A. A. (2020). Development and Validation of Unplugged Activity of Computational Thinking in Science Module to Integrate Computational Thinking in Primary Science Education. Science Education International, 31(2), 142-149. https:// doi.org/10.33828/sei.v31.i2.2

Metin, S. (2020). Activity-based unplugged coding during the preschool period. International Journal of Technology and Design Education, 0123456789. https://doi.org/10.1007/s10798-020-09616-8

NAEYC. (2004). http:/ / www.naeyc.org NAEYC Early Childhood Program Standar. 
National Association for the Education of Young Children (NAEYC), \& Fred Rogers Center. (2012). Technology and interactive nedia as tools in early childhood programs serving children from birth through age 8 .

Nieveen, N. (1999). Design Approaches and Tools in Education and Training. Springer Science \& Business Media.

Parsadaan Marga Harahap Dohot Anakboruna. (1993). Horja Adat Istiadat Dalihan Natolu. PT Grafitri.

Prastowo, A. (2015). Panduan Kreatif Membuat Bahan Ajar Inovatif. Diva Press.

Ranjabar, J. (2006). Sistem Sosial Budaya Indonesia Suatu Pengantar. Ghalia Indonesia.

Ryanto \& Sugianti. (2020). Penelitian pengembangan model addie dan r2d2: teori dan praktik. Lembaga Academic \& Research Institute.

Sugiyono. (2018). Metode Penelutian Pendidikan Pendekatan Kuantitatif, Kualitatif, dan R\&D. Alfabeta.

Wing, J. M. (2008). Computational thinking and thinking about computing. Philosophical Transactions of the Royal Society A: Mathematical, Physical and Engineering Sciences, 366(1881), 3717-3725. https://doi.org/10.1098/rsta.2008.0118

Winkel, W. (2009). Psikologi Pengajaran. Media Abadi. 